\title{
Manufacturing facility location and sustainability: A literature review and research agenda
}

Lujie Chen, Jan Olhager and Ou Tang

Linköping University Post Print

Tweet

N.B.: When citing this work, cite the original article.

Original Publication:

Lujie Chen, Jan Olhager and Ou Tang, Manufacturing facility location and sustainability: A literature review and research agenda, 2014, International Journal of Production Economics, (149), 154-163.

http://dx.doi.org/10.1016/j.ijpe.2013.05.013

Copyright: Elsevier

http://www.elsevier.com/

Postprint available at: Linköping University Electronic Press

http://urn.kb.se/resolve?urn=urn:nbn:se:liu:diva-102696 


\title{
Manufacturing facility location and sustainability: A literature review and research agenda
}

\author{
Lujie Chen ${ }^{\mathrm{a}, *}$, Jan Olhager ${ }^{\mathrm{b}}$, Ou Tang $^{\mathrm{a}}$ \\ ${ }^{a}$ Department of Management and Engineering, Linköping University, SE-581 83 Linköping, Sweden \\ ${ }^{b}$ Department of Industrial Management and Logistics, Lund University, SE-221 00 Lund, Sweden \\ * Corresponding author. Tel.: +46-13-281770; fax: +46-13-281101. \\ E-mail addresses: lujie.chen@liu.se (Lujie Chen), jan.olhager@tlog.lth.se (Jan Olhager), ou.tang@liu.se (Ou \\ Tang)
}

\begin{abstract}
A B S TR ACT
The perspectives on the manufacturing footprint of global firms are widening from the economic aspects to also include the environmental and social aspects. Thus, sustainability is becoming an important issue for the location of manufacturing facilities. It is therefore timely to review the relevant aspects and dimensions in the extant literature to investigate the relationship between sustainability and facility location. In this paper, we aim to understand how sustainability aspects are included in decision-making concerning manufacturing facility locations and the role of location in evaluating manufacturing sustainability. We examine the literature streams on sustainability and facility location. A comprehensive search includes peer-reviewed literature from 1990 to 2011. We propose a literature classification scheme with respect to focal area and research methodology. The content analysis identifies the environmental, social and economic perspectives and factors affecting location decisions. We synthesize the findings into a framework for taking sustainability aspects into account in manufacturing facility location decision-making. We also propose a research agenda for further research on sustainable locations.
\end{abstract}

Keywords:

Corporate social responsibility (CSR), Environment, Facility location, Manufacturing, Sustainability 


\section{Introduction}

The facility location problem has been around for a long time. In general, it concerns the geographical positioning of facilities for a specific organizational entity, such as a company. As such, it is a strategic decision related to the configuration of the manufacturing network. As competition becomes global and the complexity of the environment in which companies operate is increasing, managing an integrated international network has become an increasingly important task for managers (Ferdows, 1997, 2009). Traditionally, the objective has been to derive a cost-optimal distribution of facilities with respect to the location of markets (customers) and raw materials (suppliers). More recently, access to skills and knowledge has been added as a major strategic factor that affects location decisions (Ferdows 1997, Vereecke et al. 2006, and Feldmann and Olhager 2013). Manufacturing companies that have more than one plant can gain insights on markets, products, and processes by managing a group of plants as a manufacturing network. In practice, this can lead to a complete reconfiguration of the manufacturing network such as in the cases of Digital (Arntzen et al. 1995) and Procter \& Gamble (Camm et al. 1997). In other cases, the changes to the manufacturing network may be more incremental such as opening up of a new facility or closing down an existing one. There may be different strategic reasons for the location decisions for different manufacturing facilities, such as access to low-cost manufacturing, proximity to market, and access to skills and knowledge (Ferdows, 1997). Thus, deciding on the "optimal" set and location of manufacturing facilities is becoming increasingly difficult.

The literature on facility location can be broadly classified into two areas: factor assessment and mathematical approaches. The factor assessment approach often has a focus on strategic issues in decision making and it can be generalized into four steps: (i) establish the critical success factors of the business, (ii) assess options for regional manufacturing configurations, (iii) define a number of potential sites, and (iv) rank the most suitable solutions (Reid and Sanders, 2010). Implicitly, economic performance has been the driver for selecting critical success factors. Also, the mathematical approaches are typically formulated as cost minimization and profit maximization problems; cf. e.g. Melo et al. (2009), and Drezner and Hamacher (2004). Thus, the economic dimension of sustainability has historically dominated the location problem.

However, environmental and social issues have gained in importance in recent years as organizations seek competitive advantage (Dou and Sarkis 2010, Kleindorfer et al. 2005, and Seuring and Müller 2008). Technology and geopolitics enable and accelerate the 
companies to extend their manufacturing network globally. Also, the customer and supply bases are increasingly global. With wider manufacturing footprint, global markets, and global supply base, the question of location is becoming increasingly important, particularly for the facilities that are owned by the manufacturing company. The economic, environmental, and social dimensions make up the so-called triple bottom line (3BL) accounting report concerning the relationship of profit, people, and the planet (the 3 P's); cf. Kleindorfer et al. (2005). Many authors refer to the UN Brundtland Commission (WCED, 1987) concerning the overarching objective of sustainable development; i.e. "meeting the needs of the present without comprising the ability of future generations to meet their own needs".

Consequently, it is becoming increasingly necessary for manufacturing firms to include all aspects and dimensions of sustainability in their manufacturing facility location decisions. Even when a facility is selected locally, there is need to integrate sustainability factors to reach economic, social, and environmental benefits from local innovation and collaboration with local customers and suppliers (Theyel, 2012). The right location choice can help the company gain competitive advantages and improve operational performance; not only in the short term but also in the long term. For example, environmental degradation is becoming an important concern in manufacturing industry. When manufacturers outsource to a low-cost countries, operations may be halted for months due to water scarcity, earthquakes, and thunderstorms (Economy and Lieberthal, 2007). Economy and Lieberthal (2007) propose that multinational companies should proactively implement environmental protection efforts, for instance by introducing programs to build facilities and develop technologies that are required for environmental protection. Also, corporate social responsibility (CSR) aspects concerning cultural difference and ethical values should also be taking into consideration when a manufacturing network is extending into multiple countries. Underage labor may be considered a normal means for survival in some countries, but is not ethically acceptable in many developed countries.

The research literature on the combination of manufacturing facility location and sustainability is still at an early stage but growing. Terouhid et al. (2012) found 38 papers in their review, focusing on location and siting models. Therefore, it is timely to conduct a broad analysis of the state of the art on sustainability aspects related to manufacturing facility location, by providing a systematic literature review, synthesize the findings into a framework and identifying areas for future research. In this review, we perform an independent and structured search strategy with a broader focus than Terouhid et al. (2012) and identify 81 papers (with only one common paper; Dou and Sarkis, 2010). We include both quantitative 
and qualitative research. An important feature in this review is that sustainability is explicitly included, such that economic aspects as well as environmental and social factors are taken into account in the decision-making process. Issues like reverse logistics and waste management are related to the facility location problem, but these areas are adequately discussed and reviewed in the existing literature; cf. e.g. Pokharel and Mutha (2009), Chan et al. (2010), Dekker et al. (2012), and Van der Wiel et al. (2012). Therefore, they are outside the scope of this paper.

We first present an overview of the literature review methodology. We then present the search strategy and the classification scheme, based on a content analysis. Then, the results of the literature review are presented. Finally, we present a conceptual framework and a research agenda.

\section{Methodology}

The core idea with a literature review is to summarize the state of the art in the subject field, as a basis for identifying areas in which further research would be beneficial (Rowley and Slack 2004). They state that literature reviews are important in: (i) supporting the identification of a research topic, question or hypothesis; (ii) identifying the literature to which the research will make a contribution, and contextualizing the research within that literature; (iii) building an understanding of theoretical concepts and terminology; (iv) facilitating the building of a bibliography or list of the sources that have been consulted; (v) suggesting research methods that might be useful; and (vi) analyzing and interpreting results. In conducting this literature review, we follow the general guidelines from Rowley and Slack (2004): (i) material collection, including (i) scanning documents, (ii) making notes, (iii) structuring the literature review, (iv) building the bibliography, and (v) writing the literature review. The research team, consisting of three researchers (two senior researchers and one doctoral student) have collaborated and interacted on all aspects of this literature review.

Below we discuss the key steps in conducting the literature review, in terms of (i) the search strategy, and the content analysis in terms of (ii) literature over time, (iii) literature across journals, and (iv) categorization with respect to topical areas as well as research methodologies; cf. Seuring and Müller (2008), Gold et al. (2009), and Seuring and Gold (2012). 


\subsection{Search strategy}

A comprehensive search of related research from 1990 to 2011 was applied to produce a synthesis of peer-reviewed literature. The start of the time period was chosen such that the report of the UN Brundtland Commission (WCED, 1987) served as a starting point, similar to Seuring and Müller (2008). The search strategy is based on selected databases (Business source premier, Scopus, and Web of Science), selected keywords ("sustainability" in combination with "facility location", "supply chain", or a combination of the following: "global", "international" or "network" in combination with "manufacturing", "operations", or "production"). For example, one such combination was "sustainability" + "global" + "production". We also use back-tracking to find earlier relevant sources, and forward-tracking in Web of Science to find literature that are referring to the central sources. Based on this, 140 papers were identified. Based on this list, all members of the research team made individual content analyses and evaluations. The full inter-rater agreement among all three researchers was $75.0 \%$ (105 papers). Consequently, 35 papers were subject to further analysis by all three researchers jointly. In the elimination process, we excluded papers that focused on only one dimension of sustainability or did not relate to facility location at all. Finally, 81 papers were identified. As a comparison, using only "sustainability" or "facility location" yields approximately 5.700 and 1.200 hits, respectively, in Business Source Premier. However, the 81 papers selected for this study have relevance for the relationship between sustainability and manufacturing facility location.

\subsection{Literature across journals}

The 81 articles we finally reviewed are distributed among 46 different international scientific journals. 10 journals account for 45 articles (see Table 1), while the other 36 articles are from 36 different journals. The highest numbers of articles are found in Journal of Cleaner Production, Ecological Economics, International Journal of Physical Distribution \& Logistics Management, and International Journal of Production Research. Thus, this research area is treated in specialized sustainability journals as well as in general operations management journals. 
Table 1

Distribution of articles in journals.

\begin{tabular}{|c|c|c|}
\hline Journal & $\begin{array}{c}\text { Number of } \\
\text { papers }\end{array}$ & $\begin{array}{c}\text { Percentage } \\
(\%)\end{array}$ \\
\hline Journal of Cleaner Production & 18 & $22.2 \%$ \\
\hline Ecological Economics & 5 & $6.2 \%$ \\
\hline Int. J. of Physical Distribution \& Logistics Management & 5 & $6.2 \%$ \\
\hline International Journal of Production Research & 5 & $6.2 \%$ \\
\hline International Journal of Production Economics & 2 & $2.5 \%$ \\
\hline Business Strategy and the Environment & 2 & $2.5 \%$ \\
\hline Corporate Governance & 2 & $2.5 \%$ \\
\hline Int. Journal of Operations \& Production Management & 2 & $2.5 \%$ \\
\hline Journal of Business Ethics & 2 & $2.5 \%$ \\
\hline Journal of Supply Chain Management & 2 & $2.5 \%$ \\
\hline Others & 36 & $44.4 \%$ \\
\hline
\end{tabular}

\subsection{Literature over time}

The literature on manufacturing facility location and sustainability started to appear in 1997. The first eight years (1997-2004) exhibit an unstable pattern with low numbers and a few years with no articles. The average number of publications is 1.2 per year during this period. From 2005 and onwards the number of publications shows a positive trend, reaching 19 articles in 2011.

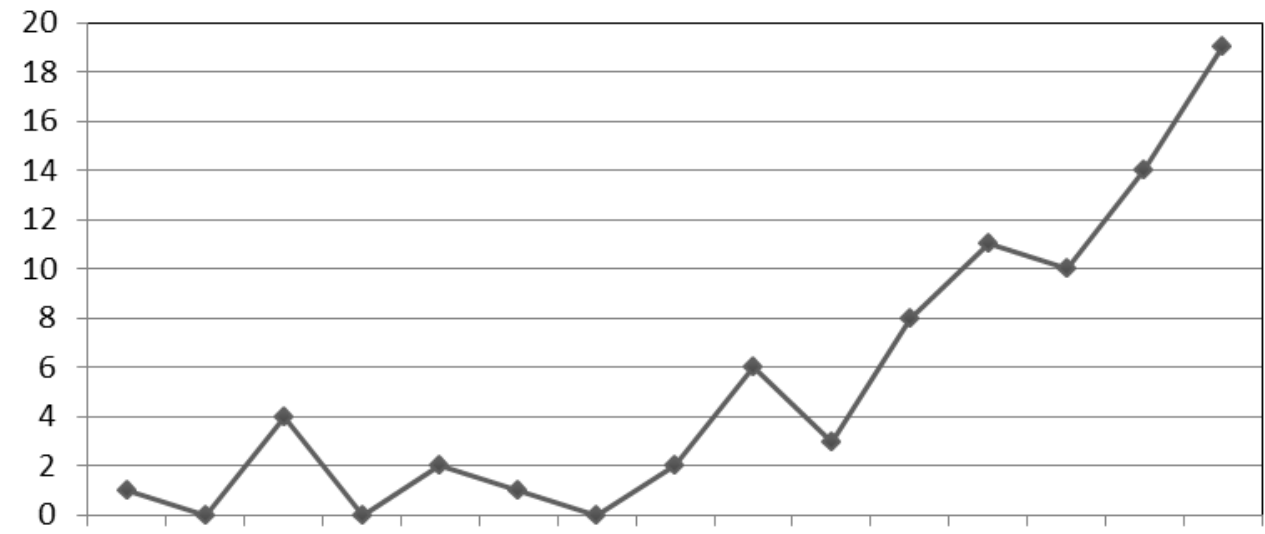

199719981999200020012002200320042005200620072008200920102011

Fig. 1. Distribution of articles over time.

\subsection{Categorization of topic area and research methodology}


When analyzing the content of the 81 articles, we could identify two dimensions for the fundamental categorization: focal area and research methodology. These are two entirely separate dimensions, since all papers can be classified in both aspects. The content analysis with respect to focal area leads us to identify four categories:

1. Papers that explicitly treat manufacturing facility location issues taking sustainability aspects into account; typically discussing and comparing alternative locations.

2. Papers that treat sustainability for a specific country or a specific geographic region.

3. Papers that discuss sustainability from a supply chain perspective; acknowledging multiple locations along a supply chain.

4. Papers discussing factors to consider for sustainable location; typically general discussions without specifically addressing a particular location.

We find five groups for the classification with respect to research methodology:

1. Conceptual modeling (potentially including simple numerical examples).

2. Case studies, including multiple case studies.

3. Surveys, based on questionnaires.

4. Mathematical modeling (or simulation).

5. Country-level data (or regional data).

The result of the two-dimensional classification of the 81 articles in this literature review is presented in Table 2. There are relatively few studies that explicitly study the relationship between manufacturing facility location and sustainability. Instead, the majority of the papers are concerned with sustainability in specific regions and for supply chain settings. Since sustainability is often related to governmental, regional, or industrial policy making, it is expected to find many papers in this category. Also, supply chains are often global and can therefore be exposed to different aspects of sustainability in different stages along the supply chain. The final category on factors to consider may appear to be small, but it should be noted that all studies on sustainability in certain regions and in supply chains all deal with factors to consider, wherefore this category only contains those studies that do not explicitly deal with specific regions or supply chains. Some papers cover supply chain issues in a specific region; these are classified here as papers concerned with sustainability in a specific region.

Each research methodology is primarily used for a particular topical area. When using surveys and statistics the topical area is typically sustainability in a certain geographical 
region, while articles that use conceptual modeling, case research and mathematical modeling/simulation primarily focus on sustainability in supply chains.

Table 2

Two-dimensional categorization of the relevant literature, with respect to content analysis and research methodology.

\begin{tabular}{|l|c|c|c|c|c|c|}
\hline \multirow{2}{*}{ Topic area } & \multicolumn{2}{|c|}{ Research methodology } & Math & $\begin{array}{c}\text { Country- } \\
\text { level data }\end{array}$ & Total \\
& Concept & Case & Survey & Math & 6 \\
\hline Sustainable locations & 1 & 3 & - & 1 & 11 & 31 \\
\hline $\begin{array}{l}\text { Sustainability in } \\
\text { specific regions }\end{array}$ & 5 & 7 & 7 & 1 & - & 38 \\
\hline $\begin{array}{l}\text { Sustainability in } \\
\text { supply chains }\end{array}$ & 13 & 14 & 2 & 9 & 1 & 6 \\
\hline Factors to consider & 2 & 3 & - & - & 11 & 81 \\
\hline Total & 21 & 27 & 9 & & 13 & 8 \\
\hline
\end{tabular}

\section{Results}

In this section we provide an overview of the literature in terms of coverage by journals, over time, and categorization.

\subsection{Sustainable locations}

As mentioned previously, there are few studies with an explicit focus on issues concerning sustainable location. In an early study by Eagan and Joeres (1997), they present an assessment tool for evaluating the sustainability at a company level, which can be applied to facility location problems. One important breakthrough, as the authors claimed, is due to its attempt to transfer the fuzzy concept of sustainability by adopting and quantifying the 16 principles for sustainable development defined by International Chamber of Commerce. Nevertheless such principles are still mainly considering the environmental aspect of sustainability.

Even though sustainability has been raised as a strategic issue in many manufacturing companies, it is seldom built into the decision model. In one recent work, Dou and Sarkis (2009) studied the location and sustainability problem with respect of offshore outsourcing. A decision process, based on analytical network process framework was developed. More important, the authors presented the location, environmental and social factors which should be considered in dealing with the problem. The latter ones, environmental and social factors have never been an emphasis in facility location literature. This study also illustrated the 
interdependence of the above mentioned factors. Such inter-dependence may also reduce the transparency of the model and increase the difficulties in understanding the decisions. Therefore, even though creating a comprehensive list for all related factors is important, it is also critical to filter the most importance factors in order to reduce the complexity of the model.

Several cases studies have been reported for investigating the sustainable location issues. These studies often limited to certain industrial sectors, such as retailing industry (Bayat et al., 2011), biofuel production (Corbiere-Nicollier, et al., 2011) and aerospace manufacturing (Varga et al., 2009). In all these recent studies, one common concern is to develop comprehensive performance measures which indicate the economic, environmental and social aspects of sustainability. A system approach can simultaneously improve the sustainability and other traditional key performance indicators of a facility such as cost. We have to note that the presented comprehensive performance measures in the above studies are very industrial-oriented. Developing a general framework for performance matrix and applying it to various industries seem a challenge task but nevertheless important for locating facilities. Also according to the above studies, the economic and environmental aspects of sustainability are relatively easy to be investigated due the existence of related regulations and data. However, the social aspect of sustainability is more difficult to be defined in different locations due to soft (intangible) measures such as culture difference.

In Reich-Weiser and Dornfeld (2009), the manufacturer location problem has been studied with the consideration of limited aspects of sustainability, namely greenhouse gas emission and consumption of water resources. Combining a quantitative model (input and output analysis) and life cycle analysis, the authors examined the tradeoffs between costs, flexibility and environment impacts. Such a model enhances the understanding of direct and indirect effects when selecting transportation modes and facility location. This study also indicates the importance of including resource availability (emission and water) in location decision making.

\section{2. $\quad$ Sustainability in specific regions}

31 articles discuss sustainability aspects for specific regions. A region is typically a country, but may include a larger region or two specific countries that are compared. For example, Boons and Mendoza (2010) discuss the definition of sustainability concerning palm oil production in Colombia and the Netherlands. Some studies use country-level statistical data to 
compare sustainability aspects between countries; see e.g. Andersson and Lindroth (2001), Bello et al. (1999), Gaughran et al. (2007) on ecological footprint, and Proops et al. (1999) on degrees of sustainability.

Many articles that address sustainability in specific regions are concerned with a specific industry or a few specific industries. Table 3 displays the articles that study explicit combinations of industry and region. The vast majority of these articles are quite recent; all except two are from 2008 and later. This indicates that industry/country analyses are a recent phenomenon; no less than six studies are from 2011. Therefore, this may be a stream of literature that will continue to expand. There are six studies on the oil, gas and bio-fuel industry in seven different countries or regions. However, the aspects that are highlighted in each study differ between the studies. This reduces the possibility to compare countries. Three more industries have more than one country study on that specific industry; these are automobile, food and textile. Still, in general there are few specific studies on specific industries in specific regions. However, the studies reported here form a baseline for further comparative studies.

Table 3

Coverage of industries and countries (or regions) and reference to the literature.

\begin{tabular}{|l|l|}
\hline Industry & Country or region (source) \\
\hline Oil / Gas / Bio-fuel & $\begin{array}{l}\text { Brazil (Hall and Matos 2010), Brazil and Switzerland (Corbiere-Nicollier et al. } \\
\text { 2011), Columbia and the Netherlands (Boons and Mendoza 2010), Italy (Valente et } \\
\text { al. 2011), UK (Stephenson et al. 2008), US (Kaffka 2009) }\end{array}$ \\
\hline Automobile & $\begin{array}{l}\text { Mexico (Vurro et al 2009), North America (Xia and Tang 2011), South Africa } \\
\text { (Barnes and Morris 2008) }\end{array}$ \\
\hline Food & New Zealand (Flint and Golicic 2009), Switzerland (Hamprecht et al. 2005) \\
\hline Textile & Brazil (Cavalcanti and De Abreu 2011), Italy (Albino and Kuhtz 2004) \\
\hline Agricultural & USA (Kaffka 2009) \\
\hline Consumer goods & Indonesia (Hidayati 2011) \\
\hline Remanufacturing & India (Rathore et al. 2011) \\
\hline Mobile phones & India (Rathore et al. 2011) \\
\hline Steel & Brazil (Cavalcanti and De Abreu 2011) \\
\hline
\end{tabular}

\subsection{Sustainability in supply chains}

There are numerous papers that address sustainability in supply chain settings. These papers do not explicitly discuss alternative facility locations, but acknowledge that there are facilities in different locations and that the supply chain needs to take various aspects of sustainability into account for long-term success. Table 4 presents an overview of the aspects and specific issues that are treated in this literature. The analytic categories were derived in an inductive 
way based on the content analysis of the papers in this review, as suggested by e.g. Rowley and Slack (2004), Seuring and Müller (2008), and Seuring and Gold (2012).

Table 4

Literature on sustainability aspects in supply chains.

\begin{tabular}{|c|c|c|}
\hline Aspect & Specific issue & Source(s) \\
\hline $\begin{array}{l}\text { Purchasing / } \\
\text { Sourcing }\end{array}$ & $\begin{array}{l}\text { Dynamic capabilities in supply management } \\
\text { Fuzzy multi-criteria evaluation framework } \\
\text { Grey system and rough sets } \\
\text { ISO } 14000 \\
\text { Multi-objective assessment based on AHP and } \\
\quad \text { fuzzy sets } \\
\text { Risk management for global sourcing }\end{array}$ & $\begin{array}{l}\text { Reuter et al. (2010) - case } \\
\text { Büyüközkan and Cifci (2011) - math } \\
\text { Bai and Sarkis (2010) - math } \\
\text { Chen (2005) - conceptual } \\
\text { Lu et al. (2007) - conceptual } \\
\text { Christopher et al. (2011) - conceptual }\end{array}$ \\
\hline SC design & $\begin{array}{l}\text { Closed-loop supply chain } \\
\text { ISO } 14001 \\
\text { Life cycle assessment } \\
\text { Multistage optimization } \\
\text { Quality and safety aspects on network design } \\
\text { and planning } \\
\text { Reverse logistics } \\
\text { System dynamics modelling }\end{array}$ & $\begin{array}{l}\text { Kleindorfer et al. (2005) - conceptual } \\
\text { Curkovic and Sroufe (2011) - case } \\
\text { Donnelly et al. (2006) - case; Facanha and Horvath } \\
\text { (2005) - math; Hutchins and Sutherland (2008) - case; } \\
\text { Linton et al. (2007) - conceptual; White (2009) - case } \\
\text { Huang et al. (2010) - math; Corsano et al. (2011) - } \\
\text { math } \\
\text { Akkerman et al. (2010) - conceptual } \\
\text { El Korchi and Millet (2011) - math } \\
\text { Purnomo et al. (2009) - math }\end{array}$ \\
\hline SC integration & $\begin{array}{l}\text { Collaborative governance } \\
\text { Impact of collaborative green practices on } \\
\text { product and process performance } \\
\text { Impact of sustainability strategy on } \\
\text { sustainability performance } \\
\text { Pollution control and prevention } \\
\text { Resource efficiency, recycling and process } \\
\text { optimization } \\
\text { Self-regulation through cooperation in the } \\
\text { supply chain }\end{array}$ & $\begin{array}{l}\text { Vurro et al. (2009) - conceptual } \\
\text { Vachon and Klassen (2008) - survey } \\
\text { Wolf (2011) - case } \\
\text { Vachon and Klassen (2007) - survey } \\
\text { Schliephake et al. (2009) - case } \\
\text { DeMan and Burns (2006) - case }\end{array}$ \\
\hline $\begin{array}{l}\mathrm{SC} \\
\text { management }\end{array}$ & $\begin{array}{l}\text { Adoption of sustainability initiatives in } \\
\text { multinational companies } \\
\text { Analysis based on complex systems modeling } \\
\text { Batch traceability and collaboration } \\
\text { Eco-efficiency and eco-intensity } \\
\text { Energy efficiency } \\
\text { Framework } \\
\text { Natural resource based view of the firm } \\
\text { Productivity and quality and the effect on } \\
\text { shareholder value } \\
\text { Relationship between multinational } \\
\text { companies and non-governmental } \\
\text { organizations } \\
\text { Relationship between innovation power and } \\
\text { sustainability strategies } \\
\text { Role of SMEs in global supply chain }\end{array}$ & $\begin{array}{l}\text { Colicchia et al. (2011) - case } \\
\text { Higgins et al. (2010) - conceptual } \\
\text { Hamprecht et al. (2005) - case } \\
\text { Schmidt and Schwegler (2008) - math } \\
\text { Van Hoek and Johnson (2010) - case } \\
\text { Carter and Rogers (2008) - conceptual; Melnyk et al. } \\
\text { (2010) - conceptual; Seuring and Müller (2008) - } \\
\text { conceptual } \\
\text { Markley and Davis (2007) - conceptual } \\
\text { Mefford (2011) - conceptual } \\
\text { Perez-Aleman and Sandilands (2008) - case } \\
\text { Van Bommel (2011) - conceptual } \\
\text { Moore and Manring (2009) - conceptual }\end{array}$ \\
\hline
\end{tabular}

These papers discuss a variety of supply chain aspects for upstream as well as downstream operations. Life cycle assessment for supply chain design is treated in five papers, of which 
three are based on case research. Three other papers present frameworks for sustainability in supply chains. All other perspectives on sustainability in supply chain are treated in individual papers. Thus, the literature on sustainability in supply chains so far provides a scattered perspective, wherefore more research is needed.

\subsection{Factors to consider}

Even though only 6 articles were classified as discussing factors to consider when dealing with manufacturing facility location and sustainability, all articles in this literature review do bring up issues to that the respective authors feel should be considered in this context. One specific aspect is the dimensions of the concept of sustainability, i.e. economic, environmental, and social sustainability. Figure 2 captures the number of articles that consider two of these dimensions or all three. It is clear that the environmental and economic issues dominate, and that the research on the social aspects of sustainability with relevance for manufacturing facility location is lagging. In the 48 papers covering all dimensions the social dimension is typically underrepresented.

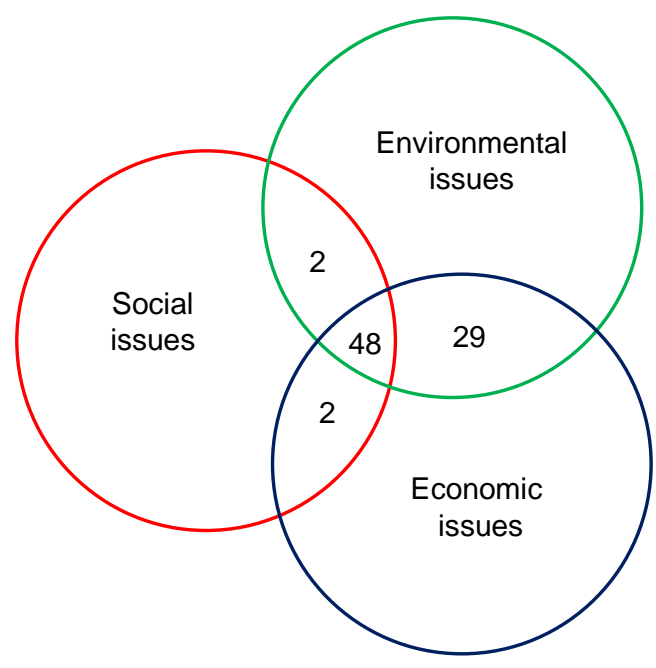

Fig. 2. Distribution of articles with respect to coverage of the 3 sustainability dimensions.

The aspects that have some relevance for sustainability and manufacturing facility location are many. In table 5 we structure and summarize the factors as well as provide reference to the literature sources. The structure is based on the Environmental Performance Index (EPI, 2010), the Sustainability Reporting Guidelines by the Global Reporting Initiative (GRI, 2012), and location factors by Dou and Sarkis (2010), Ramstetter (2011), and Somlev and Hoshino (2005). The table provides a three-level structure of the three dimensions, identifying 
literature sources that take the respective factors and sub-areas into account. We find that some areas have received a lot of attention from researchers while other areas have received considerably less attention. The average article addresses (only) 3.3 factors. Consequently, there is room for broader perspectives. Still, it is important to investigate the impact on particular factors thoroughly in order to fully understand the factor and its role for sustainability in manufacturing facility location decision-making.

\section{Table 5}

Sustainability factors to consider when choosing manufacturing facility location.

\begin{tabular}{|c|c|c|c|}
\hline Area & Factor & Determinants of location & Source(s) \\
\hline \multirow[t]{3}{*}{ Environmental } & $\begin{array}{l}\text { Ecosystem } \\
\text { vitality }\end{array}$ & $\begin{array}{l}\text { Air pollution related to the eco- } \\
\text { system } \\
\text { Water quality related to the eco- } \\
\text { system } \\
\text { Biodiversity protection } \\
\text { Climate change performance }\end{array}$ & $\begin{array}{l}\text { Abreu (2011), Curkovic and Sroufe (2011), Dou and Sarkis } \\
\text { (2010), Ueda et al. (2009), Ukidwe and Bakshi (2005), Varga et } \\
\text { al. (2009) } \\
\text { Dou and Sarkis(2010), Varga et al. (2009) } \\
\text { Bello et al. (1999), Carter and Rogers (2008), Hall and Matos } \\
\text { (2010), Higgins et al. (2010), McClintock(1999), Mickwitz et } \\
\text { al. (2011), Perez-Aleman and Sandilands (2008), Rathore et al. } \\
\text { (2011), Ueda et al. (2009), Ukidwe and Bakshi (2005), Vachon } \\
\text { and Mao (2008), Valente et al. (2011) } \\
\text { Bello et al. (1999), Carter and Rogers (2008), Higgins et al. } \\
\text { (2010), Huang et al. (2010), Linton et al. (2007), Rathore et al. } \\
\text { (2011), Reich-Weiser and Dornfeld (2009), Stephenson et al. } \\
\text { (2008), Ueda et al. (2009), Vachon and Klassen (2007), Vachon } \\
\text { and Mao (2008), Valente et al. (2011), Varga et al. (2009) }\end{array}$ \\
\hline & $\begin{array}{l}\text { Environmental } \\
\text { health }\end{array}$ & $\begin{array}{l}\text { Environmental burden of disease } \\
\text { Air pollution related to humans } \\
\text { Water quality related to humans }\end{array}$ & $\begin{array}{l}\text { Abreu (2011), Christopher et al. (2011), Closs et al. (2011), Dou } \\
\text { and Sarkis (2010), Higgins et al. (2010), McClintock (1999), } \\
\text { Perez-Aleman and Sandilands (2008), Ueda et al. (2009) } \\
\text { Abreu (2011), Dou and Sarkis (2010), Ueda et al. (2009), } \\
\text { Ukidwe and Bakshi (2005) } \\
\text { Dou and Sarkis (2010) }\end{array}$ \\
\hline & $\begin{array}{l}\text { Environmental } \\
\text { factors within } \\
\text { production }\end{array}$ & $\begin{array}{l}\text { Renewable resources } \\
\text { Waste generation } \\
\text { Waste treatment } \\
\text { Waste disposal } \\
\text { Recycling of material, energy, and } \\
\text { waste }\end{array}$ & $\begin{array}{l}\text { Abreu (2011), Lu et al. (2007), Mickwitz et al. (2011) } \\
\text { Akkerman et al. (2010), Bello et al. (1999), Brown (2009), } \\
\text { Curkovic and Sroufe (2011), Donnelly et al. (2006), Kleindorfer } \\
\text { et al. (2005), Rathore et al. (2011), Reich-Weiser and Dornfeld } \\
\text { (2009), Stephenson et al. (2008), Ueda et al. (2009), Vachon } \\
\text { and Klassen (2007), Valente et al. (2011), Vurro et al. (2009) } \\
\text { Abreu (2011), Dou and Sarkis (2010), Linton et al. (2007), } \\
\text { Mickwitz et al. (2011), Proops et al. (1999), Reich-Weiser and } \\
\text { Dornfeld (2009), Ukidwe and Bakshi (2005), Wolf (2011) } \\
\text { Dellink et al. (1999), Christopher et al. (2011), Curkovic and } \\
\text { Sroufe (2011), Dou and Sarkis (2010), Eagan and Joeres (1997), } \\
\text { Posch (2010), Rathore et al. (2011), Schliephake et al. (2009) } \\
\text { Chen (2005), Dou and Sarkis (2010), Posch (2010), Rathore et } \\
\text { al. (2011), Schmidt and Schwegler (2008), Vachon and Klassen } \\
\text { (2007), Zhu and Sarkis (2007) } \\
\text { Albino and Kuhtz (2004), Colicchia et al. (2011), Corsano et al. } \\
\text { (2011), Curkovic and Sroufe (2011), De Man and Burns (2006) } \\
\text { Albino and Kuhtz (2004), Colicchia et al. (2011), Corsano et al. } \\
\text { (2011), Higgins et al. (2010), Kleindorfer et al. (2005), Posch } \\
\text { (2010), Rao and Holt (2005), Schliephake et al. (2009), Vachon } \\
\text { and Mao (2008) }\end{array}$ \\
\hline
\end{tabular}


Table 5 (continued)

\begin{tabular}{|c|c|c|c|}
\hline Area & Factor & Determinants of location & Source(s) \\
\hline \multirow[t]{7}{*}{ Social } & Governance & $\begin{array}{l}\text { Political stability } \\
\text { Trade and tariff barriers }\end{array}$ & $\begin{array}{l}\text { Jorgensen and Knudsen (2006), Bai and Sarkis (2010), Barnes } \\
\text { and Morris (2008), Closs et al. (2011), De Man and } \\
\text { Burns(2006), Dou and Sarkis (2010), Hall and Matos(2010), } \\
\text { Reuter et al. (2010), Wolf (2011) } \\
\text { Dou and Sarkis (2010) } \\
\text { Chen (2005), Christopher et al. (2011), De Man and Burns } \\
\text { (2006), Zhu and Sarkis (2007) }\end{array}$ \\
\hline & Education & General education level & $\begin{array}{l}\text { Hutchins and Sutherland (2008), McClintock (1999), Perez- } \\
\text { Aleman and Sandilands (2008), White (2009), Vurro et al. } \\
\text { (2009) }\end{array}$ \\
\hline & Individual & $\begin{array}{l}\text { Civil liberties } \\
\text { Human rights }\end{array}$ & $\begin{array}{l}\text { Perez-Aleman and Sandilands (2008) } \\
\text { Jorgensen and Knudsen (2006), Carter and Rogers (2008), } \\
\text { Perez-Aleman and Sandilands (2008), Reuter et al. (2010), } \\
\text { Vurro et al. (2009) }\end{array}$ \\
\hline & Community & Equity & $\begin{array}{l}\text { Carter and Rogers (2008), Hutchins and Sutherland (2008), } \\
\text { Perez-Aleman and Sandilands (2008) }\end{array}$ \\
\hline & & Safety & Hutchins and Sutherland (2008) \\
\hline & & Cohesion & $\begin{array}{l}\text { Bai and Sarkis (2010), Dou and Sarkis (2010), } \\
\text { Rathore et al. (2011) }\end{array}$ \\
\hline & & Local technology & $\begin{array}{l}\text { Barnes and Morris (2008), Bello et al. (1999), Christopher et al. } \\
\text { (2011), Closs et al. (2011), Dou and Sarkis (2010), Hall and } \\
\text { Matos (2010), Milberg (2008), Rathore et al. (2011), Tate et al. } \\
\text { (2010), Varga et al. (2009), Xia and Tang (2011) }\end{array}$ \\
\hline \multirow[t]{11}{*}{ Economic } & Cost & Labor cost & $\begin{array}{l}\text { Carter and Rogers (2008), Hall and Matos (2010), Hutchins and } \\
\text { Sutherland (2008), Kleindorfer et al. (2005), Mefford (2011), } \\
\text { Valente et al. (2011), Van Hoek and Johnson (2010), Xia and } \\
\text { Tang (2011) }\end{array}$ \\
\hline & & Energy cost & Bayat et al. (2011), Carter and Rogers (2008) \\
\hline & & Material cost & Kleindorfer et al. (2005) \\
\hline & & Facility cost & Christopher et al. (2011) \\
\hline & & Logistic cost & Ueda et al. (2009) \\
\hline & Market & International markets & $\begin{array}{l}\text { Boons and Mendoza (2010), Chen (2005), Curkovic and Sroufe } \\
\text { (2011), Flint and Golicic (2009), Purnomo et al. (2009) }\end{array}$ \\
\hline & & Potential demand & $\begin{array}{l}\text { Huang et al. (2010), Rathore et al. (2011), Reuter et al. (2010), } \\
\text { Ueda et al. (2009) }\end{array}$ \\
\hline & $\begin{array}{l}\text { Economic } \\
\text { stability }\end{array}$ & Favorable tax & $\begin{array}{l}\text { Jorgensen and Knudsen(2006), Christopher et al. (2011), } \\
\text { Colicchia et al. (2011), Closs et al. (2011), Donnelly et al. } \\
\text { (2006), Dou and Sarkis (2010), Hutchins and Sutherland (2008), } \\
\text { Milberg (2008), Seuring and Müller (2008), Ueda et al. (2009), } \\
\text { Vurro et al. (2009) }\end{array}$ \\
\hline & & Exchange rate fluctuations & $\begin{array}{l}\text { Akkerman et al. (2010), Barnes and Morris (2008), Christopher } \\
\text { et al. (2011), Mefford (2011), Milberg (2008), Proops et al. } \\
\text { (1999) }\end{array}$ \\
\hline & Suppliers & $\begin{array}{l}\text { Proximity to key suppliers } \\
\text { Potential high quality suppliers }\end{array}$ & $\begin{array}{l}\text { Christopher et al. (2011), Schliephake et al. (2009), Wolf (2011) } \\
\text { Dou and Sarkis (2010) }\end{array}$ \\
\hline & Growth & $\begin{array}{l}\text { Industry growth } \\
\text { Competitiveness in the host region }\end{array}$ & $\begin{array}{l}\text { Milberg (2008) } \\
\text { Jorgensen and Knudsen (2006) }\end{array}$ \\
\hline
\end{tabular}




\section{Framework for sustainability in manufacturing facility location decision-making}

We propose a conceptual framework for synthesizing different perspectives on sustainability and manufacturing facility location for industrial firms that combines two key elements. First, firms should evaluate sustainability on an integrated viewpoint on the economic, environmental and social perspectives and aspects; for example the "triple-bottom-line". However, only selected aspects of sustainability have been highlighted in literature. Second, we add the manufacturing strategy dimension of the industrial firm, that is largely absent in the current literature on sustainability with relevance to facility location. Even though strategies for how to deal with sustainability per se or for separate dimensions such as an environmental strategy (Yang and Sheu, 2007) are discussed in the literature, the corporate and business strategy perspective is missing. Fine et al. (2002) present a framework for value chain decision-making that synthesizes strategic value added based on qualitative models and economic value added based on quantitative models. Similarly, we believe that the strategic perspective concerning e.g. competitive position, markets, and technology should be added to the sustainability aspects. To some extent in literature, strategic issues may have been incorporated in the economic dimension of sustainability. However, as described by Fine et al. (2002), the economic dimension is fundamentally only concerned with cost-related issues and lacks the long-term strategic perspective. In particular, decisions on the global manufacturing footprint of the industrial firm must include both the strategy and sustainability perspectives. Also, the global footprint should not be restricted to the manufacturing network of the firm, but should also incorporate the entire supply network. We use the basic structure and idea of synthesis in Fine et al. (2002) for developing our framework, and add the environmental and social aspects; as illustrated in Figure 3. 


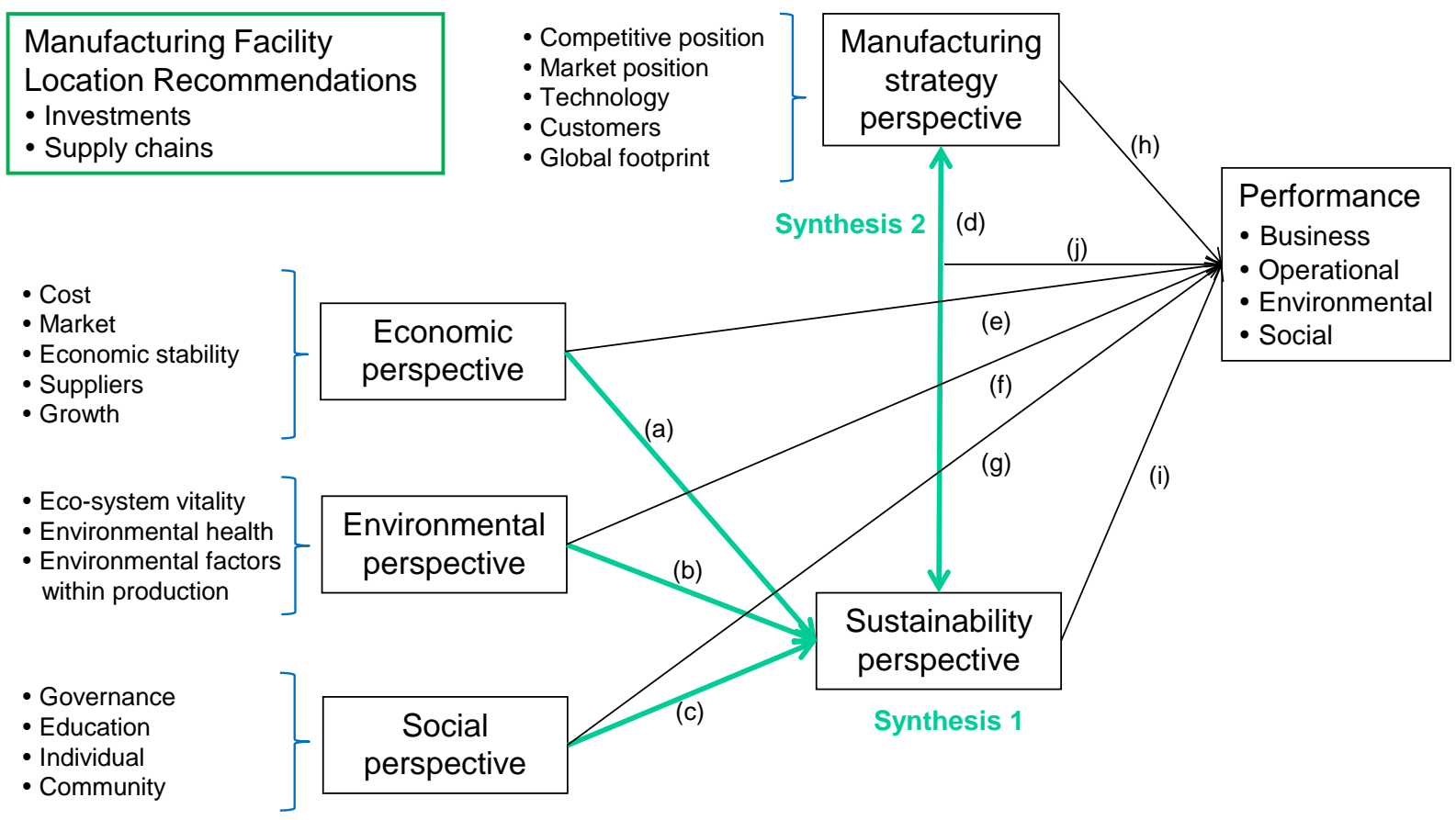

Fig. 3. Conceptual framework for sustainability in manufacturing facility location decisionmaking.

The framework in Figure 3 includes two levels of synthesis. First, the economic, environmental, and social perspectives are synthesized to the sustainability perspective. This is represented in Figure 3 by arrows (a), (b), and (c). As mentioned before, the aim of this synthesis is to provide an integrated viewpoint on the sustainability perspectives. Based on the important factors identified in previous research, Table 5 presents a list of major factors to be considered during this synthesis process. Even though many studies have integrated the three aspects of sustainability, there are very few studies that have treated sustainability with facility location as a focus. In this literature review, we only identified six papers (cf. section 3.1). Eagan and Joeres (1997) provided a sustainability assessment tool at the company level. Dou and Sarkis (2009) researched sustainability and location problems with an offshore outsourcing focus. Reich-Weiser and Dornfeld (2009) analyzed the environment impacts on emission and water in location decision-making. Other researchers have considered specific industries, such as retailing (Bayat et al., 2011), biofuel production (Corbiere-Nicollier et al., 2011) and aerospace manufacturing (Varga et al., 2009). This synthesis process - with facility location as a focus - apparently needs further development.

Second, the sustainability and manufacturing strategy perspectives are synthesized (arrow d) for making informed decisions on the global manufacturing footprint. The aim of this synthesis is to establish the strategic position so that manufacturing capability of the 
company fits the need from the market (or customer) side. This synthesis process could be even more of a challenge for the average manufacturing company, since the manufacturing strategy and sustainability perspectives should be carefully combined to bring added values to the market. This type of research with relevance for facility location is largely missing.

The framework also suggests that there are multiple effects on the performance of the firm, as well as multiple dimensions of firm performance. Arrows (e), (f), (g), and (h) represent the direct effects from the economic, environmental, social, and strategic perspectives, while arrow (i) represent the effect from the sustainability synthesis and arrow (j) the effect from the second level of synthesis between strategy and sustainability. Firm performance can be differentiated between business performance (e.g. market share, profitability, and growth), operational performance (not only cost, but also including e.g. quality, delivery, and flexibility, i.e. the main competitive priorities), environmental performance, and social performance.

Both decision-making and performance measures need to be balanced. It is important that all perspectives in Figure 3 are taken into account when making decisions that affect the global footprint and it is important to have a balanced view on the performance of the firm. The fundamental idea of the balanced scorecard (Kaplan and Norton, 1992) can be applied here, in that a balanced view is needed between all perspectives. Figge et al. (2002) extended the work of Kaplan and Norton (1992) by proposing a sustainability balanced scorecard, which can serve as a starting point for developing balanced views on strategy and sustainability.

\section{Research agenda}

We have identified some areas which deserve further research attention. In summary, these make up a research agenda for sustainability in manufacturing facility location decisionmaking. There are many answers yet to be found - and maybe even questions yet to be raised - concerning how to locate manufacturing facilities in a sustainable way, i.e. economically, environmentally, as well as socially in the long term.

\subsection{The practical dimension}


We encourage more case research to provide better understanding of the enablers and barriers for sustainable global location experienced by industrial firms. Would this differ between different geographical regions? Would this differ depending on the origin of the company? Even though there are some studies that compare countries at the country-level, there are very few studies that do this for specific industries. Such studies are important to be able to account for industry as a control variable, particularly if the set of industries varies considerably between the countries that are compared. The benefits, limitations and challenges may well differ in different regions of the world. An identification and analysis of such factors would be beneficial for manufacturing firms in their decision-making processes for facility locations.

\subsection{Social aspects relevant to manufacturing facility location}

So far, the social perspective has been largely absent in frameworks with relevance to decision-making concerning manufacturing location. The other two dimensions of sustainability have received much more attention, while research on the social aspects has been lagging, at least when it comes to including these in sustainability frameworks. Recently, Klassen and Vereecke (2012) discussed the social dimension for supply chain management in general, including the relationship with environmental performance, with some reference to geographical location. However, further studies on social factors and how these relate to location issues are needed. How should social factors be measured? Do companies and the society have the same view on social factors, or is there a need for a distinction between these entities?

\subsection{Synthesizing the economic, environmental, and social perspectives}

If a full sustainability perspective is to be developed for manufacturing facility location, all three dimensions need to be synthesized. There are three dimensions to this synthesis: content, process and context. Models that provide balanced approaches with respect to content should be developed in order to properly organize the economic, environmental, and social perspectives, and indicate the interaction of these perspectives. The process dimension, i.e. how companies create the synthesis, is largely missing. This indicates that research on organization aspects and implementation models are needed. The context dimension is concerned with external contingency factors, such as country and industry (see also section 5.1 and Table 3), that may affect operational choices. There is a need for the identification of 
contingency factors that can explain why different circumstances may imply different balances between the three dimensions.

\subsection{Adding the strategic perspective}

The manufacturing strategy perspective is not included in the sustainability aspects. For example, what should be basis for the competitive position of the firm, which markets or customers should be targeted, which technologies should be mastered and pursued, etc. The strategy approach per se may be proactive, reactive or value-seeking, which may or may not influence the approach to sustainability. Even though the literature on sustainability advocates a proactive or value-seeking approach (see e.g. Yang and Sheu, 2007), the reality may well be different. Studies on the relationship between strategy and sustainability are of the utmost interest; see e.g. Carraher et al. (2008) and Baumgartner and Korhonen (2010) for discussions on general strategic management perspective on sustainability. If sustainability is truly on the strategic agenda, integrated approaches that aim at synthesizing corporate and business strategy with sustainability should be present. In manufacturing networks with multiple locations, the distribution of sustainability management is a concern. For example, should centrally-driven global approaches be used or should each plant be allowed to build its own sustainability strategy? And how does this relate to the strategy formation of the company concerning decision-making on new manufacturing locations? The fundamental research question relates to the synthesis of the strategic and sustainability perspectives. This area offers wide possibilities for new and important research.

\subsection{Testing and expansion of the framework}

The framework in Figure 3 lends itself to empirical testing using surveys. The four perspectives (strategic, economic, environmental, and social) and sub-areas can be converted to constructs. First, measurement models need to be developed and validated for each construct. Then, practice-performance relationships can be studied. The framework suggests that there are both direct and indirect effects on performance, which can be tested using structural equations modeling techniques. Empirical testing of the framework can also include elements that potentially can enrich the framework and provide a richer understanding of the relationships among sustainability, strategy, and performance. 


\section{Concluding remarks}

The literature of relevance for manufacturing facility location has been classified and reviewed. We can conclude that sustainability is an area that is gaining interest. Still, more research is needed, since there are very few studies that explicitly treat sustainability when making decisions on facility location. This paper contributes with a summary of perspectives, factors, and approaches on all aspects on sustainability. We hope that this review can be a useful and inspirational source for further research on sustainability, manufacturing facility location and global operations footprints.

\section{References}

Abreu, M.C.D., 2011. Effects of environmental pressures on company sustainability strategies: An interview study among Brazilian manufacturing firms. International Journal of Management 28 (3), 909-925.

Akkerman, R., Farahani, P., Grunow, M., 2010. Quality, safety and sustainability in food distribution: a review of quantitative operations management approaches and challenges. OR Spectrum, 32 (4), 863-904.

Albino, V., Kuhtz, S., 2004. Enterprise input-output model for local sustainable development - the case of a tiles manufacturer in Italy. Resources Conservation and Recycling, 41 (3), 165-76.

Andersson, J.O., Lindroth, M., 2001. Ecologically unsustainable trade. Ecological Economics 37 (1), 113-22.

Arntzen, B.C., Brown, G., Harrison, T.P., Trafton, L.L., 1995. Global supply chain management at Digital Equipment Corporation. Interfaces, 25 (1), 69-93.

Bai, C., Sarkis, J., 2010. Integrating sustainability into supplier selection with grey system and rough set methodologies. International Journal of Production Economics, 124 (1), 252-64.

Barnes, J., Morris, M., 2008. Staying alive in the global automotive industry: what can developing economies learn from South Africa about linking into global automotive value chains? European Journal of Development Research, 20 (1), 31-55.

Baumgartner, R.J., Korhonen, J., 2010. Strategic thinking for sustainable development. Sustainable Development 18 (2), 71-75.

Bayat, A., Sundararajan, S., Gustafson, H.R., Zimmers, E.W., 2011. Sustainably driven supply chains. Industrial Engineer, 43 (8), 26-31.

Bello, P., Wackernagel, M., Suarez Guerrero, A.I., Mendez Garcia, J., Linares, A.C., Guadalupe Suarez Guerrero, M., Onisto, L., Falfan, I.S.L., 1999. National natural capital accounting with the ecological footprint concept. Ecological Economics, 29 (3), 375-90.

Boons, F., Mendoza, A., 2010. Constructing sustainable palm oil: how actors define sustainability. Journal of Cleaner Production, 18 (16/17), 1686-95.

Büyüközkan, G., Cifci, G., 2011. A novel fuzzy multi-criteria decision framework for sustainable supplier selection with incomplete information. Computers in Industry, 62 (2), 164-174.

Carter, C.R., Rogers, D.S., 2008. A framework of sustainable supply chain management: moving toward new theory. International Journal of Physical Distribution \& Logistics Management 38 (5), 360-387.

Camm, J.D., Chormann, T.E., Dill, F.A., Evans, J.R., Sweeney, D.J., Wegryn, G.W., 1997. Blending OR/MS, judgment, and GIS: restructuring P\&G's supply chain. Interfaces, 27 (1), 128-42.

Carraher, S.M., Buckley, M.R., Carraher, C.E., 2008. Research challenges in sustainable strategic management: change and sustainability. International Journal of Sustainable Strategic Management 1 (1), 2-15.

Chan, H.K., Yin, S., Chan, F.T.S., 2010. Implementing just-in-time philosophy to reverse logistics systems: a review. International Journal of Production Research 48 (21), 6293-6313. 
Chen, C.-C., 2005. Incorporating green purchasing into the frame of ISO 14000. Journal of Cleaner Production $13(9), 927-933$.

Christopher, M., Mena, C., Khan, O., Yurt, O., 2011. Approaches to managing global sourcing risk. Supply Chain Management 16 (2), 67-81.

Closs, D., Speier, C., Meacham, N., 2011. Sustainability to support end-to-end value chains: the role of supply chain management. Journal of the Academy of Marketing Science 39 (1), 101-116.

Colicchia, C., Melacini, M., Perotti, S., 2011. Benchmarking supply chain sustainability: insights from a field study. Benchmarking: An International Journal 18 (5), 705-732.

Corbiere-Nicollier, T., Blanc, I., Erkman, S., 2011. Towards a global criteria based framework for the sustainability assessment of bioethanol supply chains - Application to the Swiss dilemma: Is local produced bioethanol more sustainable than bioethanol imported from Brazil? Ecological Indicators 11 (5), 1447-1458.

Corsano, G., Vecchietti, A.R., Montagna, J.M., 2011. Optimal design for sustainable bioethanol supply chain considering detailed plant performance model. Computers \& Chemical Engineering 35 (8), 1384-1398.

Curkovic, S., Sroufe, R., 2011. Using ISO 14001 to promote a sustainable supply chain strategy. Business Strategy and the Environment 20 (2), 71-93.

Dekker, R., Bloemhof, J., Mallidis, I., 2012. Operations research for green logistics - An overview of aspects, issues, contributions and challenges. European Journal of Operational Research 219 (3), 671-679.

De Man, R., Burns, T.R., 2006. Sustainability: Supply chains, partner linkages, and new forms of self-regulation. Human Systems Management 25 (1), 1-12.

Dellink, R., Bennis, M., Verbruggen, H., 1999. Sustainable economic structures. Ecological Economics 29 (1), 141.

Donnelly, K., Beckett-Furnell, Z., Traeger, S., Okrasinski, T., Holman, S., 2006. Eco-design implemented through a product-based environmental management system. Journal of Cleaner Production 14 (15-16), 1357-1367.

Dou, Y., Sarkis, J., 2010. A joint location and outsourcing sustainability analysis for a strategic offshoring decision. International Journal of Production Research 48 (2), 567-592.

Drezner, Z., Hamacher, H.W. (Eds.), 2004. Facility Location: Applications and Theory. New York: Springer.

Eagan, P.D., Joeres, E., 1997. Development of a facility-based environmental performance indicator related to sustainable development. Journal of Cleaner Production 5 (4), 269-278.

Economy, E., Lieberthal, K., 2007. Scorched earth. Harvard Business Review 85 (6), 88-96.

El Korchi, A., Millet, D., 2011. Designing a sustainable reverse logistics channel: the 18 generic structures framework. Journal of Cleaner Production 19 (6-7), 588-597.

EPI, 2010. 2010 environmental performance index summary for policy makers. Yale Centre for Environmental Law and Policy, Yale University and Center for International Earth Science Information Network, Columbia University.

Facanha, C., Horvath, A., 2005. Environmental assessment of logistics outsourcing. Journal of Management in Engineering 21 (1), 27-37.

Feldmann, A., Olhager J, 2013, Plant roles: Site competence bundles and their relationships with site location factors and performance, International Journal of Operations and Production Management 33 (6), in press.

Ferdows, K., 2009. Shaping global operations. Journal of Globalization, Competitiveness, \& Governability 3 (1), 136-148.

Ferdows, K., 1997. Making the most of foreign factories, Harvard Business Review 75 (2), 73-88.

Fine, C.H., Vardan, R., Pethick, R., El-Hout, J., 2002. Rapid-response capability in value-chain design. MIT Sloan Management Review, 43 (2), 69-75.

Figge, F., Hahn, T., Schaltegger, S., Wagner, M., 2002. The sustainability balanced scorecard - linking sustainability management to business strategy, Business Strategy and the Environment 11 (5), 269-284.

Flint, D.J., Golicic, S.L., 2009. Searching for competitive advantage through sustainability: A qualitative study in the New Zealand wine industry. International Journal of Physical Distribution \& Logistics Management 39 (10), 841-860.

Gaughran, W.F., Burke, S., Phelan, P., 2007. Intelligent manufacturing and environmental sustainability. Robotics \& Computer-Integrated Manufacturing 23 (6), 704-711.

Gold, S., Seuring, S., Beske, P., 2010. Sustainable supply chain management and inter-organizational resources: a literature review. Corporate Social Responsibility and Environmental Management, 17, 230-245. 
Gonzalez-Benito, J., Gonzalez-Benito, O., 2010. A study of determinant factors of stakeholder environmental pressure perceived by industrial companies. Business Strategy and the Environment 19 (3), 164-181.

GRI, 2012. Global reporting initiative - sustainability reporting guidelines (version 3.1). (http://www.globalreporting.org; Access: Mar 30, 2012).

Hall, J., Matos, S., 2010. Incorporating impoverished communities in sustainable supply chains. International Journal of Physical Distribution \& Logistics Management 40 (1/2), 124-147.

Hamprecht, J., Corsten, D., Noll, M., Meier, E., 2005. Controlling the sustainability of food supply chains. Supply Chain Management 10 (1), 7-10.

Hidayati, N.D., 2011. Pattern of corporate social responsibility programs: A case study. Social Responsibility Journal 7 (1), 104-117.

Higgins, A.J., Miller, C.J., Archer, A.A., Ton, T., Fletcher, C.S., McAllister, R.R.J., 2010. Challenges of operations research practice in agricultural value chains. Journal of the Operational Research Society 61 (6), 964-973.

Hill, M.R., 2001. Sustainability, greenhouse gas emissions and international operations management. International Journal of Operations \& Production Management 21 (12), 1503-1520.

Huang, Y., Chen, C.-W., Fan, Y., 2010. Multistage optimization of the supply chains of biofuels. Transportation Research Part E - Logistics and Transportation Review 46 (6), 820-830.

Hutchins, M.J., Sutherland, J.W., 2008. An exploration of measures of social sustainability and their application to supply chain decisions. Journal of Cleaner Production 16 (15), 1688-1698.

Jabbour, C.J.C., Santos, F.C.A., Nagano, M.S., 2008. Environmental management system and human resource practices: is there a link between them in four Brazilian companies? Journal of Cleaner Production 16 (17), 1922-1925.

Jorgensen, A.L., Knudsen, J.S., 2006. Sustainable competitiveness in global value chains: How do small Danish firms behave? Corporate Governance 6 (4), 449-462.

Kaffka, S.R., 2009. Can feedstock production for biofuels be sustainable in California? California Agriculture 63 (4), 202-207.

Kaplan, R.S., Norton, D.P., 1992. The balanced scorecard - measures that drive performance. Harvard Business Review, 70 (1), 71-79.

Klassen, R.D., Vereecke, A., 2012. Social issues in supply chains: capabilities link responsibility, risk (opportunity), and performance. International Journal of Production Economics, 140, 103-115.

Kleindorfer, P.R., Singhal, K., Van Wassenhove, L.N., 2005. Sustainable operations management. Production \& Operations Management 14 (4), 482-492.

Koplin, J., Seuring, S., Mesterharm, M., 2007. Incorporating sustainability into supply management in the automotive industry - the case of the Volkswagen AG. Journal of Cleaner Production 15 (11/12), 1053-1062.

Lenzen, M., Murray, J., 2010. Conceptualising environmental responsibility. Ecological Economics 70 (2), 261270.

Linton, J.D., Klassen, R., Jayaraman, V., 2007. Sustainable supply chains: An introduction. Journal of Operations Management 25 (6), 1075-1082.

Lu, L.Y.Y., Wu, C.H., Kuo, T.C., 2007. Environmental principles applicable to green supplier evaluation by using multi-objective decision analysis. International Journal of Production Research 45 (18-19), 4317-4331.

Markley, M.J., Davis, L., 2007. Exploring future competitive advantage through sustainable supply chains. International Journal of Physical Distribution \& Logistics Management 37 (9), 763-774.

McClintock, B., 1999. The multinational corporation and social justice: experiments in supranational governance. Review of Social Economy 57 (4), 507-522.

Mefford, R.N., 2011. The economic value of a sustainable supply chain. Business \& Society Review 116 (1), 109-143.

Melnyk, S.A., Davis, E.W., Spekman, R.E., Sandor, J., 2010. Outcome-driven supply chains. MIT Sloan Management Review 51 (2), 33-38.

Melo, M.T., Nickel, S., Saldanha-da-Gama, F., 2009. Facility location and supply chain management - a review. European Journal of Operational Research, 196 (2), 401-412.

Mickwitz, P., Hildén, M., Seppälä, J., Melanen, M., 2011. Sustainability through system transformation: lessons from Finnish efforts. Journal of Cleaner Production 19 (16), 1779-1787. 
Milberg, W., 2008. Shifting sources and uses of profits: sustaining US financialization with global value chains. Economy and Society 37 (3), 420-451.

Moore, S.B., Manring, S.L., 2009. Strategy development in small and medium sized enterprises for sustainability and increased value creation. Journal of Cleaner Production 17 (2), 276-282.

O'Brien, C., 2002. Global manufacturing and the sustainable economy. International Journal of Production Research 40 (15), 3867-3877.

Perez-Aleman, P., Sandilands, M., 2008. Building value at the top and the bottom of the global supply chain: MNC-NGO partnerships. California Management Review 51 (1), 24-49.

Pokharel,P. ,Mutha,A., 2009. Perspectives in reverse logistics: A review. Resources, Conservation and Recycling 53 (4), 175-182.

Posch, A., 2010. Industrial recycling networks as starting points for broader sustainability-oriented cooperation? Journal of Industrial Ecology 14 (2), 242-257.

Proops, J.L.R., Atkinson, G., von Schlotheim, B.F., Simon, S., 1999. International trade and the sustainability footprint: a practical criterion for its assessment. Ecological Economics 28 (1), 75-97.

Purnomo, H., Guizol, P., Muhtaman, D.R., 2009. Governing the teak furniture business: A global value chain system dynamic modelling approach. Environmental Modelling \& Software 24 (12), 1391-1401.

Ramstetter, E.D., 2011. Ranking locations for Japan's manufacturing multinationals in Asia: A literature survey illustrated with indexes. Asian Economic Journal 25 (2), 197-226.

Rao, P., Holt, D., 2005. Do green supply chains lead to competitiveness and economic performance? International Journal of Operations \& Production Management 25 (9), 898-916.

Rathore, P., Kota, S., Chakrabarti, A., 2011. Sustainability through remanufacturing in India: a case study on mobile handsets. Journal of Cleaner Production 19 (15), 1709-1722.

Reich-Weiser, C., Dornfeld, D.A., 2009. A discussion of greenhouse gas emission tradeoffs and water scarcity within the supply chain. Journal of Manufacturing Systems 28 (1), 23-27.

Reid, R.D., Sanders, N.R., 2010. Operations Management: An Integrated Approach. New York: Wiley.

Reuter, C., Foerstl, K.A.I., Hartmann, E.V.I., Blome, C., 2010. Sustainable global supplier management: the role of dynamic capabilities in achieving competitive advantage. Journal of Supply Chain Management 46 (2), 45-63.

Rowley, J., Slack, F., 2004. Conducting a literature review. Management Research News 27 (6), 31-39.

Santolaria, M., Oliver-Solà, J., Gasol, C.M., Morales-Pinzón, T., Rieradevall, J., 2011. Eco-design in innovation driven companies: perception, predictions and the main drivers of integration. The Spanish example. Journal of Cleaner Production 19 (12), 1315-1323.

Schliephake, K., Stevens, G., Clay, S., 2009. Making resources work more efficiently - the importance of supply chain partnerships. Journal of Cleaner Production 17 (14), 1257-1263.

Schmidt, M., Schwegler, R., 2008. A recursive ecological indicator system for the supply chain of a company. Journal of Cleaner Production 16 (15), 1658-1664.

Seuring, S., Müller, M., 2008. From a literature review to a conceptual framework for sustainable supply chain management. Journal of Cleaner Production 16 (15), 1699-1710.

Seuring, S., Gold, S., 2012. Conducting content-analysis based literature reviews in supply chain management. Supply Chain Management: An International Journal 17 (5), 544-555.

Somlev, I.P., Hoshino, Y., 2005. Influence of location factors on establishment and ownership of foreign investments: The case of the Japanese manufacturing firms in Europe. International Business Review 14 (15), 577-598.

Stephenson, A.L., Dennis, J.S., Scott, S.A., 2008. Improving the sustainability of the production of biodiesel from oilseed rape in the UK. Process Safety and Environmental Protection 86 (B6), 427-440.

Sutherland, J., Gunter, K., Allen, D., Bauer, D., Bras, B., Gutowski, T., Murphy, C., Piwonka, T., Sheng, P., Thurston, D., Wolff, E., 2004. A global perspective on the environmental challenges facing the automotive industry: state-of-the-art and directions for the future. International Journal of Vehicle Design 35 (1/2), 86110.

Tate, W.L., Ellram, L.M., Kirchoff, J.F., 2010. Corporate social responsibility reports: a thematic analysis related to supply chain management. Journal of Supply Chain Management 46 (1), 19-44.

Terouhid, S., Rie, R., Fard., M, 2012. Towards sustainable facility location - a literature review. Journal of Sustainable Development 5 (7), 18-34. 
Theyel, G., 2012. Production location and sustainability, International Journal of Agile Systems and Management 5 (3), 267-275.

Ueda, K., Takenaka, T., Váncza, J., Monostori, L., 2009. Value creation and decision-making in sustainable society. CIRP Annals - Manufacturing Technology 58 (2), 681-700.

Ukidwe, N.U., Bakshi, B.R., 2005. Flow of natural versus economic capital in industrial supply networks and its implications to sustainability. Environmental Science \& Technology 39 (24), 9759-9769.

Vachon, S., Klassen, R.D., 2007. Supply chain management and environmental technologies: the role of integration. International Journal of Production Research 45 (2), 401-423.

Vachon, S., Klassen, R.D., 2008. Environmental management and manufacturing performance: The role of collaboration in the supply chain. International Journal of Production Economics 111 (2), 299-315.

Vachon, S., Mao, Z., 2008. Linking supply chain strength to sustainable development: a country-level analysis. Journal of Cleaner Production 16 (15), 1552-1560.

Valente, C., Spinelli, R., Hillring, B.G., 2011. LCA of environmental and socio-economic impacts related to wood energy production in alpine conditions: Valle di Fiemme (Italy). Journal of Cleaner Production 19 (17/18), 1931-1938.

Van Bommel, H.W.M., 2011. A conceptual framework for analyzing sustainability strategies in industrial supply networks from an innovation perspective. Journal of Cleaner Production 19 (8), 895-904.

Van der Wiel, A., Bossink, B., Masurel, E., 2012. Reverse logistics for waste reduction in cradle-to-cradleoriented firms: waste management strategies in the Dutch metal industry. International Journal of Technology Management 60 (1/2), 96-113.

Van Hoek, R., Johnson, M., 2010. Sustainability and energy efficiency: Research implications from an academic roundtable and two case examples. International Journal of Physical Distribution \& Logistics Management $40(1 / 2), 148-158$.

Varga, L., Allen, P.M., Strathern, M., Rose-Anderssen, C., Baldwin, J.S., Ridgway, K., 2009. Sustainable supply networks: a complex systems perspective. Emergence: Complexity \& Organization 11 (3), 16-36.

Vereecke, A., Van Dierdonck, R., De Meyer, A., 2006. A typology of plants in global manufacturing networks. Management Science 52 (11), 1737-1750.

Vurro, C., Russo, A., Perrini, F., 2009. Shaping sustainable value chains: Network determinants of supply chain governance models. Journal of Business Ethics 90, 607-621.

WCED, 1987. Our Common Future (World Commission on Environment and Development, Bruntland Commission). Oxford: Oxford University Press.

White, P., 2009. Building a sustainability strategy into the business. Corporate Governance 9 (4), 386-394.

Wolf, J., 2011. Sustainable supply chain management integration: A qualitative analysis of the German manufacturing industry. Journal of Business Ethics 102 (2), 221-235.

Xia, Y., Tang, T.L.-P., 2011. Sustainability in supply chain management: suggestions for the auto industry. Management Decision 49 (4), 495-512.

Yang, C.-L., Sheu, C., 2007. Achieving supply chain environment management: an exploratory study. International Journal of Technology Management 40 (1/2/3), 131-156.

Zhu, Q., Sarkis, J., 2007. The moderating effects of institutional pressures on emergent green supply chain practices and performance. International Journal of Production Research 45 (18-19), 4333-4355. 